\title{
Az istállótrágya és mútrágya hatása a kukorica növekedésére és növekedési mutatóinak dinamikájára, eltéró évjáratokban
}

\author{
MICSKEI GYÖRGYI-JÓCSÁK ILDIKÓ-BERZSENYI ZOLTÁN \\ MTA Mezógazdasági Kutatóintézete, Martonvásár
}

\section{Összefoglalás}

Kukorica monokultúra tartamkísérletben, hatóanyag-azonosság elve alapján összehasonlítottuk az istállótrágya és a mútrágya hatását a kukorica növekedési mutatóira, három éven keresztül, 2005-2007-ben. Az istállótrágya és a mútrágya hatásának jellemzésére a növekedésanalízis mutatói közül vizsgáltuk a kukoricanövény szárazanyagprodukciójának és levélterületének abszolút növekedési rátáját (AGR), a nettó asszimilációs rátáját (NAR) és a levélterület arányát (LAR). Az eredmények értékeléséhez Hunt és Parsons (1974) által kidolgozott növekedésanalízis programot használtuk, amely magában foglalja a matematikai és statisztikai számításokat is.

Az évjárathatás elemzése elsősorban a csapadékhiány jelentős terméslimitáló hatására mutatott rá, amelynek következtében, a kísérleti kezelések hatása a kedvezôtlen évjáratokban kevésbé, vagy egyáltalán nem volt mérhetô a terméseredményekben. Ugyanakkor az évjárathatás jól jellemezhetô volt a szárazanyag-produkció dinamikájával és a levélterület eltérố szezondinamikájával.

Kulcsszavak: kukorica, szárazanyag-produkció, növekedési mutatók, Hunt-Parsons modell 


\title{
Effect of farmyard manure and mineral fertiliser on the growth and the dynamics of the growth parameters of maize in different years
}

\author{
GY. MICSKEI-I. JÓCSÁK-Z. BERZSENYI
}

Agricultural Research Institute of the Hungarian Academy of Sciences, Martonvásár

\section{Summary}

The effect of farmyard manure (FYM) and mineral fertiliser on the growth parameters of maize was compared on the principle of the equality of active ingredients during a three year interval in a long-term experiment on continuous maize, in 2005-2007. Among the parameters of growth analysis, the absolute growth rate (AGR), net assimilation rate (NAR) and the leaf area ratio (LAR) of the dry matter accumulation and the leaf area were determined in order to characterise the effect of farmyard manure and mineral fertiliser. A growth analysis program was used to evaluate the results developed by Hunt and Parsons (1974) that involves mathematical and statistical analysis.

The analysis of the year effects mainly elucidated that drought has a major yield limiting consequence in unfavourable years and as a result of which the outcome of the experimental treatments was only partially- or not, measurable on the yield. The year effect could be well characterised by the dynamics of dry matter accumulation with the different seasonal dynamics of leaf area.

Key words: maize, dry matter production, growth parameters, Hunt-Parsons model

\section{Bevezetés és irodalmi áttekintés}

A növekedésanalízis különösen alkalmas módszer a kukoricanövény fejlôdésének - mint biomassza produkciónak - és az azt befolyásoló ökológiai és agronómiai faktoroknak komparatív, összehasonlító vizsgálatára. A növekedésanalízis, amely összekötô híd a növényi produkció puszta leírása és a fiziológiai módszereket alkalmazó analízisek között (Hunt 1978) magába foglalja a növények vagy növényi szervek produkciójának kvantitatív tanulmányozását, integrálva a vizsgált rendszerekben és az ökológiailag vagy agronómiailag értelmezhetó intervallumokban. A növekedésanalízis és az ökofiziológiai vizsgálatok képezik a gerincét 
a növénytermesztési kutatások korszerú termesztésfiziológiai irányzatának. Kukorica kísérletek eredményei alapján Berzsenyi (1996) állapította meg, hogy a növekedésanalízis mutatói közül a N-hiány stressz mérésére elsôsorban a termésnövekedés sebessége (CGR) és a levélterület-index (LAI) alkalmas. A kísérleti kezelések termésstabilitását jól jellemezhetjük a stabilitásanalízis variancia és a regresszió módszerével is.

Berzsenyi és Gyôrffy (1997) megállapították, hogy azokban a kezelésekben volt legnagyobb a termés, amelyekben az istállótrágya hatóanyag-tartalmát fele arányban, illetve teljes egészében NPK-mútrágya formájában juttatták ki. Árendás és Csathó (2002) eredményei szerint az istálló- és mútrágya együttes alkalmazásának hatékonysága jobb, mint az istállótrágyáé, jól megközelíti, de nem múlja felül a mútrágyáét. A talaj termékenysége istállótrágyázás nélkül is növelhető rendszeres mútrágyázással, kukorica monokultúrában. A jó nitrogén-ellátottság mellett tovább fenntartható az optimális levélfelület index érték és a biomassza tartóssága, ami az asszimilátáknak a szemtermésbe történó áramlása szempontjából kedvező (Berzsenyi et al. 2007). Agronómiai szempontból a szárazanyag felhalmozódásnak van a legnagyobb jelentősége, ezért általánosan használják a növekedés dinamikájának mutatójaként.

Vizsgálatunk célja az volt, hogy a hatóanyag-azonosság elvén beállított trágyázási tartamkísérletben adatokat kapjunk az istálló-, ill. a mútrágyázás különbözô szintjeinek a kukoricanövény növekedésére gyakorolt hatásáról, valamint a növekedési mutatók dinamikájáról monokultúrában, eltérô évjáratokban.

\section{Anyag és módszer}

\section{Kisérleti kezelések}

A kisparcellás tartamkísérletet Martonvásáron, az MTA Mezőgazdasági Kutatóintézetének kísérleti területén, részben erodált erdőmaradványos csernozjom talajon állították be, 1959-ben. A kísérlet az alábbi 7 kezelést tartalmazza: (1) Kontroll; (2) $35 \mathrm{t} /$ ha istállótrágya; (3) 17,5 t/ha istállótrágya $+\mathrm{N}_{1 / 2} \mathrm{P}_{1 / 2} \mathrm{~K}_{1 / 2}$ mútrágya; (4) $\mathrm{N}_{1} \mathrm{P}_{1} \mathrm{~K}_{1}$ mútrágya; (5) 70 t/ha istállótrágya; (6) 35 t/ha istállótrágya $+\mathrm{N}_{1} \mathrm{P}_{1} \mathrm{~K}_{1}$ mútrágya; (7) $\mathrm{N}_{2} \mathrm{P}_{2} \mathrm{~K}_{2}$ mútrágya (a továbbiakban: 1., 2., 3., 4., 5., 6., 7. kezelés). Az évenként kijuttatott hatóanyag mennyisége (kg/ha) a 24. kezelésben: $\mathrm{N} 66, \mathrm{P}_{2} \mathrm{O}_{5} 38, \mathrm{~K}_{2} \mathrm{O} 75$; az 5-7. kezelésben: $\mathrm{N} 132, \mathrm{P}_{2} \mathrm{O}_{5} 76, \mathrm{~K}_{2} \mathrm{O}$ 150. Az istállótrágyát, valamint a P-és K-mútrágyákat 4 évente ôsszel juttatjuk ki, legutóbb 2006-ban. A N-mútrágyát 4 évre egyenletesen elosztva adagoljuk. 
A kísérletbe a Norma SC, FAO 380-as tenyészidejú martonvásári kukorica hibridet vetettünk el.

\section{Az évjárathatás}

A vizsgált három év csapadék és hőmérsékleti adatai rendkívül nagy eltéréseket mutatnak egymáshoz, valamint a 30 éves átlaghoz viszonyítva is.

2005-ben igen kedvezóen alakult az időjárás a kukorica számára mind a csapadék, mind a hőmérséklet tekintetében a vetés körüli időszakban, ami elôsegítette az ideális kelést. 2006-ban a vetés körüli időszakban a szokásos csapadékmennyiségnek csak a fele hullott, ám összességében átlagos évrôl beszélhetünk. A 2007-es év rendkívül forró volt, minden hónap átlaghômérséklete $2^{\circ} \mathrm{C}$-kal meghaladta a sokéves átlagot.

\section{Mérések}

A vizsgálatokat a növekedésanalízis destruktív (direkt) és indirekt módszereivel végeztük. A mintavételt a kukoricanövények 4 leveles fejlettségénél kezdtük meg (a vetéstől számított 22-37. napon), és a fiziológiai érésig folytattuk. A destruktív vizsgálatok során minden kezelésből és ismétlésbôl mintavételenként 3 kukoricanövényt vágtunk ki a talaj felszínénél, 14 napos intervallumokban. A növényeket a következô részekre osztottunk fel: zöld levéllemez, szár a levélhüvellyel, címer, buroklevél, csôszár, csó és szemtermés. Mértük a növényi részek nedves, illetve száraz tömegét, a levélfelületet, meghatároztuk a levélszámot. Indirekt módszerekkel növényállományban mértük a csô melletti levél területét és klorofill-tartalmát.

\section{Adatelemzés}

A kísérleti adatok biometriai értékelését Sváb (1973) módszere alapján végeztük és a kapott eredmények kiértékelésére Hunt-Parsons (1974) növekedésanalízis programját (HP modell) használtuk. A Hunt-Parsons növekedésanalízis program a stepwise regressziós módszer alapján elsófokú, másodfokú vagy harmadfokú polinomot illeszt az egész növény száraztömegéhez (Y) és az összes levélterülethez ( $\mathrm{Z}$ ), az idô (X) függvényében, illetve megadja a standard hibát és a 95\%-os konfidencia határokat (Berzsenyi 2000). A különbözô trágyázási kezelések hatásának jellemzésére a HP programmal a növekedésanalízis alábbi mutatóit számítottuk ki: (1) abszolút növekedési ráta (AGR, ALGR), (2) relatív növekedési ráta (RGR), (3) nettó asszimilációs ráta (NAR), (4) levél- 
terület arány (LAR). A kísérleti adatok feldolgozása IBM kompatibilis számítógépen, SPSS 11.0. for Windows és MSTAT-C programokkal történt.

\section{Kísérleti eredmények}

\section{Az istállótrágya és mútrágya hatása a terméseredményekre}

Mind a három vizsgált évben a kontroll kezelésben kaptuk szignifikánsan a legkisebb termést. 2005 és 2006-ban azonos tendencia mutatkozott a terméseredményekben: szignifikánsan a legmagasabb terméseket $(9,8$ és 7,7 t/ha) a 70 t/ha istállótrágyát teljes mértékben helyettesítő NPK-dózisnál kaptuk (7. kezelés), míg 2007-ben az 5. kezelésben (3,4 t/ha), azaz a 70 t/ha istállótrágya alkalmazásakor, ami az istállótrágya pozitív hatásával magyarázható száraz évjáratban. 2007-ben a magas mútrágya dózisú kezelések terméseredménye (2,4 t /ha) nem mutatott szignifikáns különbséget a kontroll kezelés terméseredményével. Az elsô két vizsgálati évben az istállótrágya + mútrágya kombináció (3. és 6. kezelés) termésre gyakorolt hatása szignifikánsan felülmúlta az istállótrágya hatását (2. és 5. kezelés), azonban alulmaradt a mútrágya formájában kijuttatott azonos NPK-hatóanyag hatásától (4. és 7. kezelés). 2007-ben a kísérleti kezelések hatása kevésbé vagy egyáltalán nem volt mérhetô a terméseredményekben. A terméslimitáló hatás a jelentôs csapadékhiánnyal magyarázható, amely rendkívül rossz termékenyülést és igen nagymértékú terméskiesést okozott (60-85\% a 2005-ös évhez képest). A kezelések hatását a kukorica szemtermésére 2005 és 2007 között, az 1. táblázat szemlélteti.

2. Az istállótrágya és mütrágya hatása a kukoricanövény szárazanyag-produkciójának dinamikájára és növekedési sebességére

A Hunt-Parsons program harmadfokú függvénnyel jellemezte az összes szárazanyag-produkció dinamikáját (1. ábra). A növekedési görbék lefutásában jelentkező különbségek mutatják meg a kezelések és az évjárat hatásait a növény növekedésére. 2005 és 2006-ban jól elkülönültek a különböző kezeléshatások: a legmagasabb szárazanyag-produkciót (278 és 267 g/nap) a 6. és a 7. kezelésben, a legalacsonyabbat (145 és $150 \mathrm{~g} / \mathrm{nap}$ ) a kontroll és a 2 . kezelésben kaptuk, míg a 3., 4., és 5. kezelés alkotta a közbülsô értékeket.

2007-ben a különböző kezelésekben kapott szárazanyag-produkció értékei jóval szúkebb határok között változtak, a legmagasabb szárazanyag-produkciót (212 és 200 g/nap) 2. és 3. kezelésben, a legalacsonyabbat (178 és $181 \mathrm{~g} / \mathrm{nap}$ ) 
a 6. és a kontroll kezelésben kaptuk. A görbék lefutását vizsgálva látható, hogy 2005-ben, az optimális csapadék ellátottságnak köszönhetôen, a növekedési idôszak végén a görbe nem mutatott maximum pontot, a növekedés tovább folytatódott.

1. táblázat. A trágyázás hatása a kukorica szemtermésére eltéró évjáratokban Martonvásár, 2005-2007

\begin{tabular}{|c|c|c|c|}
\hline \multirow{2}{*}{$\begin{array}{l}\text { Kezelések } \\
\text { (1) }\end{array}$} & \multicolumn{3}{|c|}{$\begin{array}{l}\text { Szemtermés t/ha } \\
\text { (2) }\end{array}$} \\
\hline & 2005 & 2006 & 2007 \\
\hline 1. Kontroll & 4,30 & 3,99 & 2,49 \\
\hline 2. 35 t/ha istállótrágya & 6,00 & 4,88 & 3,01 \\
\hline 3. $17,5 \mathrm{t} /$ ha istállótrágya $+\mathrm{N}_{1 / 2} \mathrm{P}_{1 / 2} \mathrm{~K}_{1 / 2}$ mútrágya & 7,70 & 6,01 & 3,18 \\
\hline 4. $\mathrm{N}_{1} \mathrm{P}_{1} \mathrm{~K}_{1}$ mütrágya & 8,00 & 6,28 & 3,11 \\
\hline 5. 70 t/ha istállótrágya & 6,81 & 5,17 & 3,35 \\
\hline 6. $35 \mathrm{t} /$ ha istállótrágya $+\mathrm{N}_{1} \mathrm{P}_{1} \mathrm{~K}_{1}$ mütrágya & 9,22 & 6,25 & 2,44 \\
\hline 7. $\mathrm{N}_{2} \mathrm{P}_{2} \mathrm{~K}_{2}$ mútrágya & 9,82 & 7,69 & 2,32 \\
\hline $\mathrm{SzD}_{5 \%}(3)$ & 0,82 & 0,95 & 0,51 \\
\hline
\end{tabular}

Table 1. Effect of fertilisation treatments on maize grain yield over years (Martonvásár, 20052007). (1) Treatments: 1 . Control; $2.35 \mathrm{t} \mathrm{ha}^{-1} \mathrm{FYM} ; 3.17 .5 \mathrm{t} \mathrm{ha}^{-1} \mathrm{FYM}+\mathrm{N}_{1 / 2} \mathrm{P}_{1 / 2} \mathrm{~K}_{1 / 2} ; 4 . \mathrm{N}_{1} \mathrm{P}_{1} \mathrm{~K}_{1} ; 5$. $70 \mathrm{t} \mathrm{ha}^{-1} \mathrm{FYM} ; 6.35 \mathrm{t} \mathrm{ha}^{-1} \mathrm{FYM}+\mathrm{N}_{1} \mathrm{P}_{1} \mathrm{~K}_{1} ; 7 . \mathrm{N}_{2} \mathrm{P}_{2} \mathrm{~K}_{2}$. (2) Grain yield tha-1, (3) $\mathrm{LSD}_{5 \%}$.

A száraz 2006-os évben, a növekedési időszak végén a szárazanyag-produkció mindegyik trágyakezelésnél a maximum elérése után határozottan csökkent. A 2007-es, aszályos évjáratban a szárazanyag-produkció maximum értékei minden kezelésben alacsonyabbak voltak és a növény korábban érte el, mint 2006ban. A statisztikai értékelés során mindhárom évben szignifikáns különbséget állapítottunk meg a kezelések között.

A szárazanyag-produkció dinamikájának trágyázástól függố eltéréseit pontosan visszatükrözi az abszolút növekedési sebesség. Az összes szárazanyag abszolút növekedési sebességének maximum és átlagos értékeivel jól lehet jellemezni az évjárathatást is (2. táblázat). A abszolút növekedési sebesség dinamikájára jellemző, hogy fokozatosan nô a maximumig és ezt követôen csökken (Berzsenyi 1996). 2005-2006-ban a kontrollkezelés abszolút növekedési sebességének görbéje jól elkülönült a többi trágyakezelés görbéjétól, de 2007 - 
ben értékei felülmúlták a 4. kezelés értékeit. A különböző kezelésekben kapott abszolút növekedési sebesség görbéire is jellemző volt, hogy szûkebb értékhatárok között változtak, mint 2005-2006-ban.

1. ábra. A trágyázási kezelések és az évjárat hatása (2005-2007) a kukoricanövény összes szárazanyag produkciójának dinamikájára és abszolút növekedési sebességére, Hunt-Parsons modell alapján
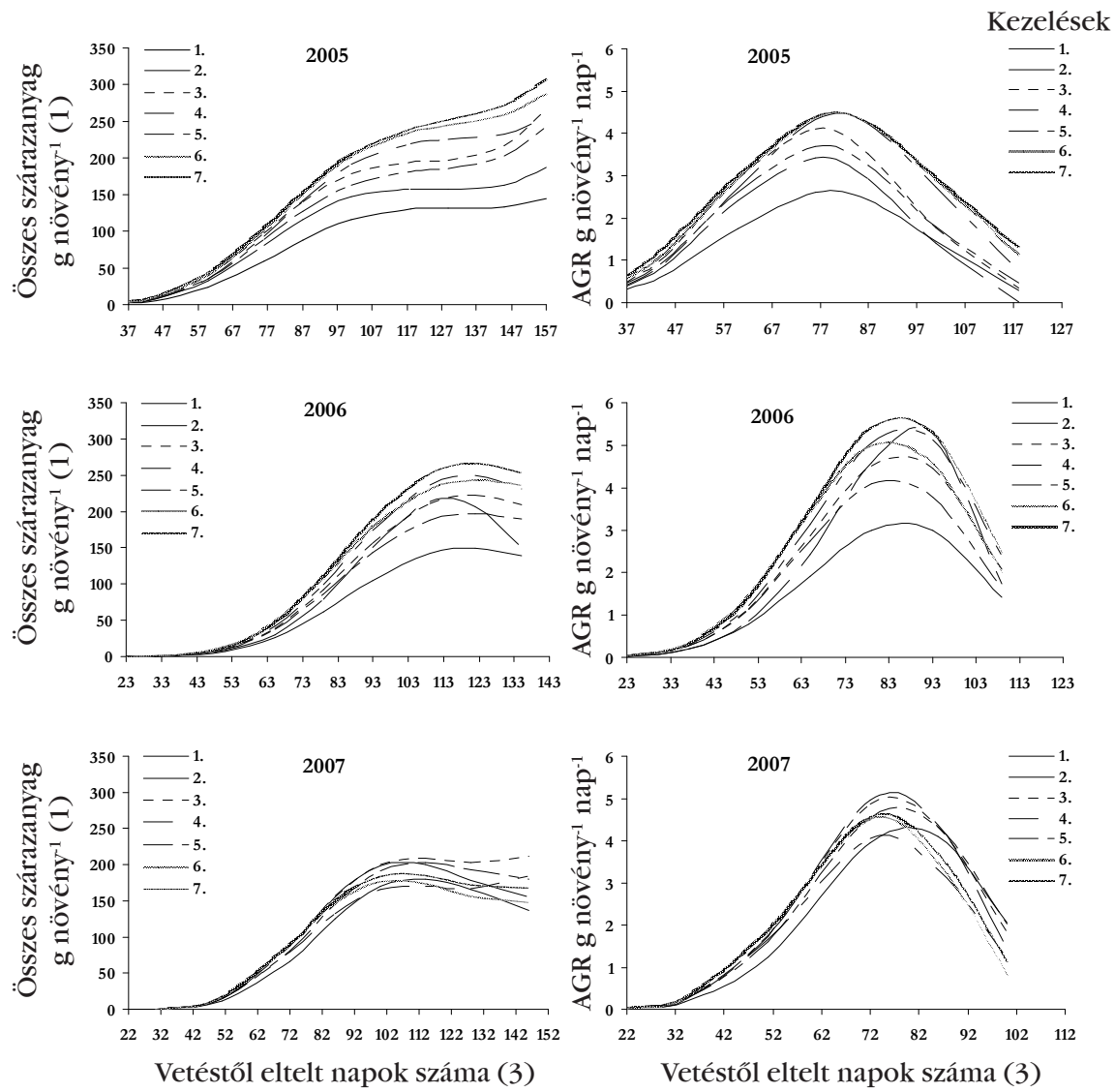

(4) Kezelések: 1. Kontroll; $2.35 \mathrm{t} /$ ha istállótrágya; 3. 17,5 t/ha istállótrágya $+\mathrm{N}_{1 / 2} \mathrm{P}_{1 / 2} \mathrm{~K}_{1 / 2}$ mútrágya; $4 . \mathrm{N}_{1} \mathrm{P}_{1} \mathrm{~K}_{1}$ mútrágya; $5.70 \mathrm{t} / \mathrm{ha}$ istállótrágya; $6.35 \mathrm{t} / \mathrm{ha}$ istállótrágya $+\mathrm{N}_{1} \mathrm{P}_{1} \mathrm{~K}_{1}$ mútrágya; 7 . $\mathrm{N}_{2} \mathrm{P}_{2} \mathrm{~K}_{2}$ mútrágya.

Figure 1. Effect of fertilisation and years (2005-2007) on the dynamics of total dry matter production and absolute growth ratio of the maize plant based on the Hunt-Parsons model. (1) Dry matter $g$ plant $^{1}$, (2) Absolute growth rate (AGR) g plant ${ }^{-1}$ day $^{1}$, (3) Number of days from sowing, (4) Treatments: 1. Control; 2. 35 tha $^{-1}$ FYM; 3.17 .5 tha $^{-1}$ FYM $+\mathrm{N}_{1 / 2} \mathrm{P}_{1 / 2} \mathrm{~K}_{1 / 2} ; 4 . \mathrm{N}_{1} \mathrm{P}_{1} \mathrm{~K}_{1} ; 5.70$ t hat ${ }^{-1} \mathrm{FYM} ; 6.35 \mathrm{t} \mathrm{ha}^{-1}$ $\mathrm{FYM}+\mathrm{N}_{1} \mathrm{P}_{1} \mathrm{~K}_{1} ; 7 . \mathrm{N}_{2} \mathrm{P}_{2} \mathrm{~K}_{2}$. 


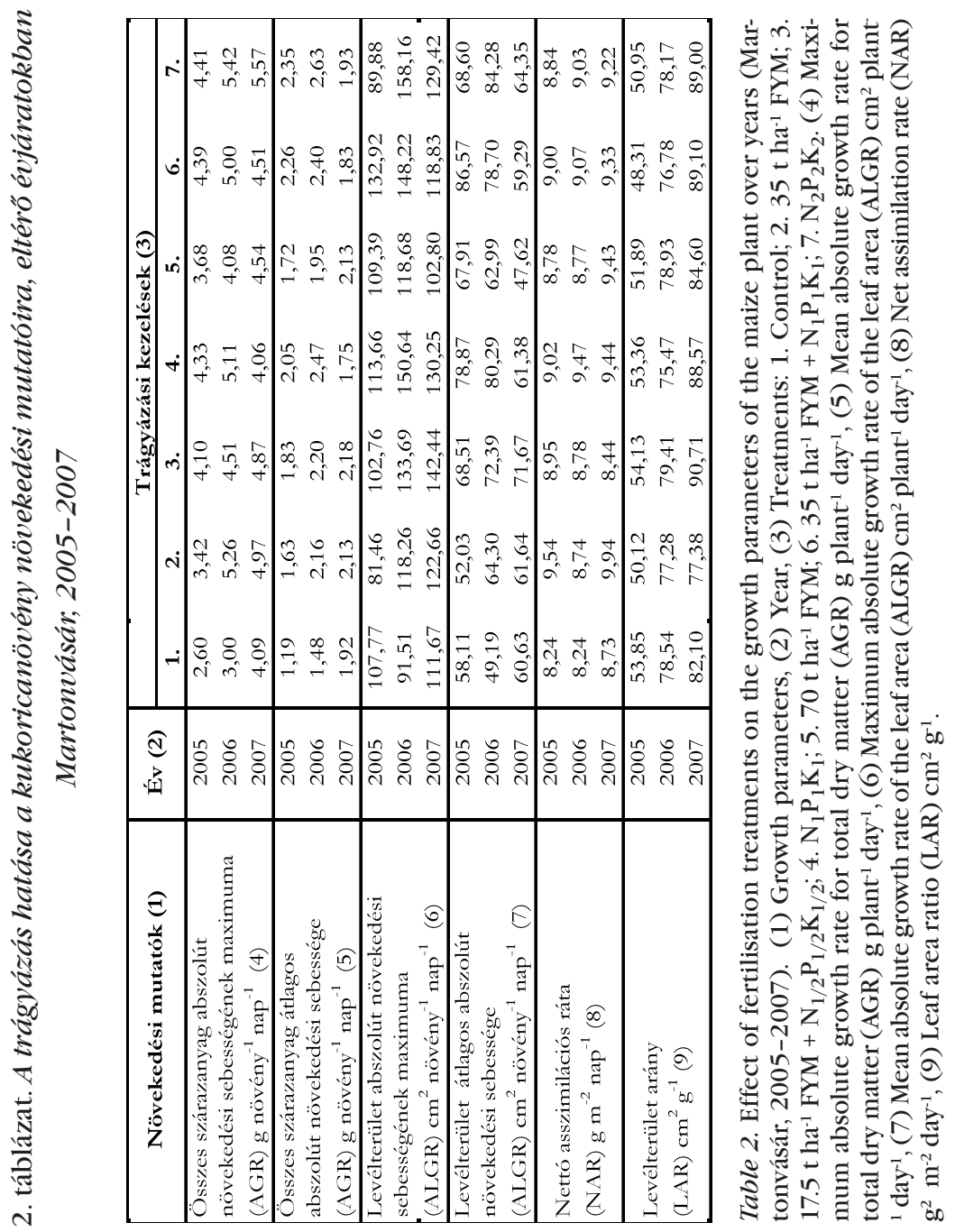


3. Az istállótrágya és mútrágya hatása a levélterület szezondinamikájára és növekedési sebességére

A trágyakezelések és az évjárat hatását a levélterület szezonális dinamikájával és az abszolút növekedési sebességgel (ALGR) is jellemeztük. A Hunt-Parsons program 2005-ben másodfokú, 2006-ban másod- és harmadfokú, 2007-ben harmadfokú függvényt illesztett a levélterület növekedés dinamikájához. A levélterület szezonális dinamikájában 2005-ben és 2006-ban a hét kezeléshatás jól elkülöníthető volt, míg 2007-ben a kezelések közötti különbségek jelentősen lecsökkentek (2. ábra). 2005-ben a maximális levélterület értékek az 1. és 2. kezelésben voltak a legalacsonyabbak $\left(3716,4241 \mathrm{~cm}^{2}\right)$, és a 6 . és 7 . kezelésben a legmagasabbak $\left(5390,5990 \mathrm{~cm}^{2}\right)$. 2005-ben a levélterület maximális értékei minden kezelésben négy hétig tartósan megmaradtak, ami biztosította az ideális körülményeket a termés kialakulásához. 2006-ban nôtt a kezelések közötti különbség a levélterület maximális értékében. Legalacsonyabb a kontroll kezelésben $\left(3353 \mathrm{~cm}^{2}\right)$, legmagasabb a 7 . kezelésben $\left(5845 \mathrm{~cm}^{2}\right)$ volt. 2006-ban a 2. és 5. kezelésekben a levélterület maximális értékei csak két hétig maradtak fenn, míg a többi kezelés esetében több, mint négy héten keresztül. 2007-ben a 7., 6. és 4. kezelésben kaptuk a legmagasabb levélterület maximum értékeket (5690-5346 $\mathrm{cm}^{2}$ ), amely csak igen rövid ideig maradt fenn, s a maximum elérése után hirtelen csökkenni kezdett. A 3. kezelésben kapott levélterület dinamikájának görbéje elkülönül a többi kezeléstől. A 2007 nyarán bekövetkezett jelentős csapadékhiány az 1., 2. és 5 . kezelés esetében okozott jelentős csökkenést a levélterület maximum értékekben (4533-4486 cm²), ami jelentős kihatással volt a termésképződésre is. A varianciaanalízis a levélterület értékek szignifikáns különbségét mutatta ki a különböző kezelésekben, minden vizsgált évben.

A levélterület növekedését jellemzi a növekedés fokozódása a maximumig, majd fokozatos csökkenése, egészen a növekedés befejezôdéséig, azaz a 0 pont eléréséig. Ezt követően a levélterület erőteljes csökkenésének időszaka következik és tart a minimum pontig, amely után a leszáradás sebessége csökken. A levélterület abszolút növekedési sebességének maximum és átlagos értékeivel jól lehet jellemezni az évjárathatást is (2. táblázat).

Az abszolút növekedési sebesség maximumát azonos időben mértük 2005ben (vetés utáni 60. napon) és 2006-ban is (vetés utáni 65. napon) minden kezelésben, míg 2007-ben az 1., 2., 3. és 5. kezelés esetében három héttel korábban (a vetés utáni 50. napon), mint a 4., 6. és 7. kezelésben (vetés utáni 
70. napon). 2006-ban a levélterület növekedése minden kezelésben közel azonos idôpontban fejezôdött be (a vetés utáni 88-93. nap között).

2. ábra. A trágyázási kezelések és az évjárat hatása (2005-2007) a kukoricanövény levélterület szezondinamikájára és abszolút növekedési sebességére, Hunt-Parsons modell alapján
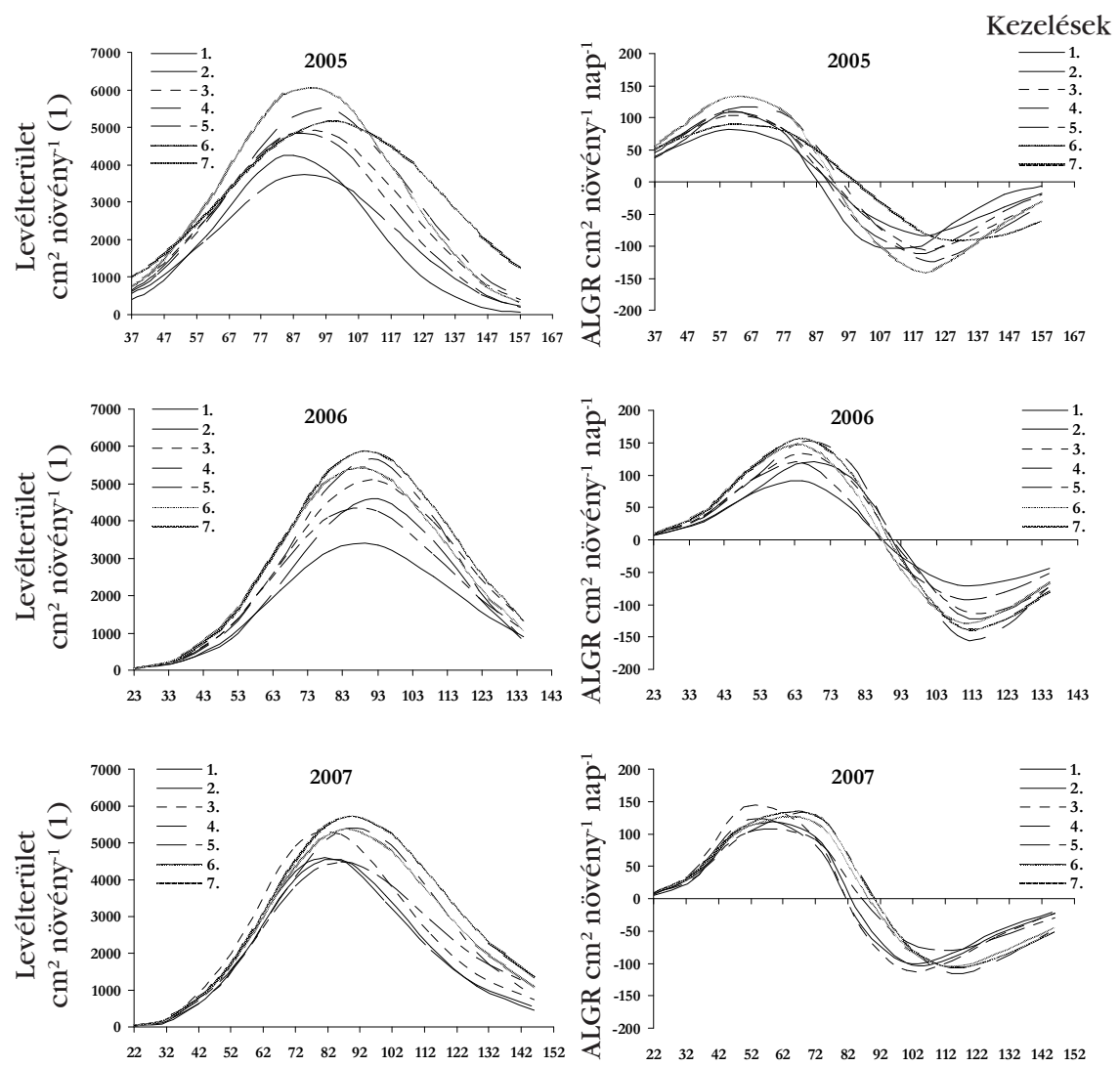

Vetéstől eltelt napok száma (3)

Vetéstől eltelt napok száma (3)

(4) Kezelések: 1. Kontroll; 2.35 t/ha istállótrágya; $3.17,5$ t/ha istállótrágya $+\mathrm{N}_{1 / 2} \mathrm{P}_{1 / 2} \mathrm{~K}_{1 / 2}$ mútrágya; 4. $\mathrm{N}_{1} \mathrm{P}_{1} \mathrm{~K}_{1}$ mútrágya; 5.70 t/ha istállótrágya; 6.35 t/ha istállótrágya $+\mathrm{N}_{1} \mathrm{P}_{1} \mathrm{~K}_{1}$ mútrágya; 7. $\mathrm{N}_{2} \mathrm{P}_{2} \mathrm{~K}_{2}$ mútrágya.

Figure 2. Effect of fertilisation and years (2005-2007) on the seasonal dynamics of the leaf area and the absolute growth ratio of the maize plant based on the Hunt-Parsons model. (1) Leaf area $\mathrm{cm}^{2}$ plant ${ }^{-1}$, (2) Leaf area growth rate (ALGR) $\mathrm{cm}^{2}$ plant ${ }^{-1}$ day $^{-1}$, (3) Number of days from sowing, (4) Treatments: 1. Control; 2. $35 \mathrm{t} \mathrm{ha}^{-1} \mathrm{FYM} ; 3.17 .5 \mathrm{t} \mathrm{ha}^{-1} \mathrm{FYM}+\mathrm{N}_{1 / 2} \mathrm{P}_{1 / 2} \mathrm{~K}_{1 / 2} ; 4 . \mathrm{N}_{1} \mathrm{P}_{1} \mathrm{~K}_{1} ; 5.70$ t ha-1 FYM; 6. $35 \mathrm{t} \mathrm{ha}^{-1} \mathrm{FYM}+\mathrm{N}_{1} \mathrm{P}_{1} \mathrm{~K}_{1} ; 7 . \mathrm{N}_{2} \mathrm{P}_{2} \mathrm{~K}_{2}$. 
4. Az istállótrágya és mútrágya hatása a növekedési mutatók átlagos és maximális értékeire

A mintavételi adatok feldolgozása során a növekedési mutatókat először trágyázási kezelésenként számítottuk ki, mindegyik mintavételi idôszakra. A növekedési mutatók közül az AGR, az ALGR, az RGR, a NAR, és a LAR mutatók átlagos és maximális értékeit határoztuk meg Hunt et al. (2002) módszere alapján.

A NAR (fiziológiai jellemzó), és a LAR (morfológiai jellemzó) átlagos értékét kezelésenként és évenként a 2. táblázat tartalmazza. A nettó asszimilációs ráta a kezelések átlagában 2007-ben volt a legmagasabb $\left(9,22 \mathrm{~g} / \mathrm{m}^{2} / \mathrm{nap}\right)$, míg 2005 és 2006-ban alacsonyabb értékeket kaptunk (8,91 és 8,87 g/ $\mathrm{m}^{2} / \mathrm{nap}$ ), $\mathrm{s}$ közöttük szignifikáns különbséget nem találtunk. 2007-ben az aszályos, de igen meleg idójárás eredményezte a nagy levélfelületet, ami a levélterület arány értékeiben is megmutatkozott, a kezelések átlaga $85,92 \mathrm{~cm}^{2} / \mathrm{g}$ volt. 2006ban a LAR átlagos értéke $77,80 \mathrm{~cm}^{2} / \mathrm{g}, 2005$-ben $51,80 \mathrm{~cm}^{2} / \mathrm{g}$ értékkel volt jellemezhetô.

\section{Következtetések}

A varianciaanalízis eredményei alapján megállapítottuk, hogy a különbözô szintû́ istálló-, és mútrágya kezelések jelentôsen befolyásolják a növény szárazanyag-felhalmozódásának dinamikáját és a levélterület növekedését. Az eltérô trágyakezelések szignifikánsan befolyásolják a szárazanyag produkció növekedési rátáját (AGR), a levélterület abszolút növekedési rátáját (ALGR), a nettó aszszimilációs rátát (NAR) és a levélterület arányt (LAR). Az évjárathatás jól jellemezhetô a szárazanyag produkció dinamikájával és a levélterület eltérô szezondinamikájával. Az összes szárazanyag és a levélterület abszolút növekedési sebességének maximum és átlagos értékei szintén jól jellemezik az eltérô évjáratok hatását.

\section{IRODALOM}

Árendás, T.-Csathó, P.: 2002. Comparison of the effect of equivalent nutrients given in the form of farmyard manure or fertilizers in Hungarian long-term field trials. Commun. Soil Sci. Plant Anal. 30: 2861-2878. 
Berzsenyi Z.: 1996. A N-mútrágyázás hatásának vizsgálata a kukorica (Zea mays L.) növekedésére Hunt-Parsons modellel. Növénytermelés. 45. 1: 35-52.

Berzsenyi Z.-Gyórffy B.: 1997. Az istállótrágya és a mútrágya hatása a kukorica (Zea mays L.) termésére és termésstabilitására monokultúra tartamkísérletben. Növénytermelés. 46. 4: 509-527.

Berzsenyi, Z.: 2000. Növekedésanalízis a növénytermesztésben. Egyetemi jegyzet PhD hallgatóknak. Pannon Agrártudományi Egyetem Georgikon Mezőgazdaságtudományi Kar, Keszthely.

Berzsenyi, Z.-Lap, D. Q.-Micskei, Gy.-Sugár, E.-Takács, N.: 2007. Effect of maize stalks and $\mathrm{N}$ fertilisation on the yield and yield stability of maize (Zea mays L.) grown in a monoculture in a long-term experiment. Cereal Res. Commun. 35: 249-252.

Hunt, R.: 1978. Plant growth analysis. Studies in Biology. No. 96. Arnold. London.

Hunt, R.-Causton, D. R.-Shipley, B.-Askew, P.: 2002. A modern tool for classicalplant growth analysis. Annal of Botany. 90: 485-488.

Hunt, R.-Parsons, I. T.: 1974. A computer program for deriving growth-functions in plant growth analysis. J. Appl. Ecol. 11: 297-307.

Sváb J.: 1973. Biometriai módszerek a mezőgazdasági kutatásban. Mezőgazdasági Kiadó. Budapest.

A szerzők levelezési címe - Address of the authors:

Micskei Györgyi-Jócsák Ildikó-dr. Berzsenyi Zoltán

MTA Mezőgazdasági Kutatóintézete

Martonvásár

Brunszvik u. 2.

H-2462 